MEDICINE AND THE LAW

\title{
Age discrimination in critical care triage in South Africa: The law and the allocation of scarce health resources in the COVID-19 pandemic
}

N Erasmus, BA Hons, LLB, HDip Company Law, MBA, Attorney of the High Court and Independent Corporate Counsel

Honorary Lecturer in Health Law, Unit for Undergraduate Medical Education, School of Clinical Medicine, Faculty of Health Sciences, University of the Witwatersrand, Johannesburg, South Africa

Corresponding author: $N$ Erasmus (nicolette.erasmus@wits.ac.za)

\begin{abstract}
No one may be refused emergency medical treatment in South Africa (SA). Yet score-based categorical exclusions used in critical care triage guidelines disproportionately discriminate against older adults, the cognitively and physically impaired, and the disabled. Adults over the age of 60 , who make up $9.1 \%$ of the SA population, are most likely to present with disabilities and comorbidities at triage. Score-based models, drawn from international precedents, deny these patients admission to an ICU when resources are constrained, such as during influenza and COVID-19 outbreaks. The Critical Care Society of Southern Africa and the South African Medical Association adopted the Clinical Frailty Scale, which progressively withholds admission to ICUs based on age, frailty and comorbidities in a manner that potentially contravenes constitutional and equality prohibitions against unfair discrimination. The legal implications for healthcare providers are extensive, ranging from personal liability to hate speech and crimes against humanity. COVID-19 guidelines and score-based triage protocols must be revised urgently to eliminate unlawful discrimination against legally protected categories of patients in SA, including the disabled and the elderly. That will ensure legal certainty for health practitioners, and secure the full protections of the law to which the health-vulnerable and those of advanced age are constitutionally entitled.
\end{abstract}

S Afr Med J 2020;110(12):1172-1175. https://doi.org/10.7196/SAMJ.2020.v110i12.15344

In March 2020, the World Health Organization (WHO) declared COVID-19 a global pandemic. ${ }^{[1]}$ Without a cure, critically ill patients were dying in hospital corridors and waiting rooms in northern Italy, sitting in their chairs, with too few critical care beds and ventilators to meet demand. ${ }^{[2]}$ Arguments ensued in the Northern Hemisphere about who should be denied ventilators: ${ }^{[3]}$ the cognitively or physically impaired, ${ }^{[4]}$ the old, ${ }^{[5]}$ or those presenting with an array of comorbidities ${ }^{[6]}$ Old age - the common denominator in all three topped the list. ${ }^{[7]}$

\section{COVID-19 triage protocols}

Intensive care units (ICUs) function at close to maximum capacity at the best of times, around $80 \%$ and $50 \%$ in the public and private sectors, respectively ${ }^{[8]}$ Predicting ICU mortality and 6-month survival odds to determine who would benefit most from admission to an ICU during triage, frontline physicians, nurses ${ }^{[9]}$ and internists ${ }^{[10]}$ beat objective score-based systems consistently. ${ }^{[11]}$ Yet it is score-based protocols such as Sequential Organ Failure Assessment (SOFA) that are routinely used to justify the exclusion of entire categories of patients from ICUs. ${ }^{[12-14]}$

The Critical Care Society of Southern Africa (CCSSA), for example, compiled a score-based emergency triage consensus guideline in 2019 $9^{[15]}$ and a COVID-19 triage guideline in 2020. ${ }^{[16]}$ Age is used as tie-breaker, so that the older the patient, the lower they rank in priority for ICU admission. The South African Medical Association (SAMA) adopted the CCSSA Clinical Frailty Scale (CFS) in its COVID-19 triage guidelines, ${ }^{[17]}$ in which even the mildly frail (evident slowing, needing help with shopping) are excluded from admission to an ICU.

Disabilities and comorbidities naturally increase with age. ${ }^{[18]}$ Pre-pandemic ventilator guidelines in other countries justified the indirect, and ostensibly lawful, exclusion of older adults from admission to ICUs based on this fact. ${ }^{[13]}$

\section{Constitutional imperatives}

In South African (SA) law, ${ }^{[19]}$ both direct and indirect unfair discrimination ${ }^{[20]}$ based on age, mental and physical disability, and HIV/AIDS status are prohibited (Promotion of Equality and Prevention of Unfair Discrimination Act 4 of 2000, ${ }^{[21]}$ section 1: 'discrimination', 'prohibited grounds', and sections 12 - 14). The inclusion of even a single unfair provision renders the guidelines actionable: discrimination is presumed unfair in terms of the SA Constitution, unless and until established as objectively fair by a court, ${ }^{[21]}$ or reasonably and justifiably limited by a law of general application (Constitution, ${ }^{[19]}$ sections 9 and 36). The CCSSA and SAMA triage guidelines discriminate on at least these four prohibited grounds.

A landmark SA case, Soobramoney v Minister of Health, KwaZuluNatal, ${ }^{[22]}$ held that the state may limit scarce chronic life-saving healthcare in futile cases, but not emergency care. Constitutionally, no one may be refused emergency medical treatment, which is binding on all ${ }^{[19]}$ (sections 8 and 27(3)). Without express legal endorsement, there can be no justification for the CCSSA and SAMA triage guidelines to deny patients admission to an ICU on the prohibited grounds of belonging to a particular age group or matching a predetermined frailty score. ${ }^{[23]}$

Where, why and how have SA triage guidelines erred? Some $9.1 \%$ of the SA population, approximately 5.4 million people, are over the age of 60 years. ${ }^{[2]}$ With an average life expectancy of another 17.5 years, ${ }^{[25]}$ the potential for mass casualties in this age group as a result of prejudicial triage protocols is extensive. 
Compared with one critical care reference two decades ago, ${ }^{[26]}$ modern triage guidelines seem shockingly expedient. ${ }^{[15]}$

Within weeks of the COVID-19 pandemic hitting Europe and North America, a public outcry arose regarding prejudicial treatment of the elderly and the disabled. ${ }^{[27,28]}$ Against the threat of legal action, ${ }^{[29]}$ medical authorities ${ }^{[30,31]}$ moved quickly to amend categorical exclusions to avoid the impression that some lives were 'not worth saving. ${ }^{[14]}$

Where the CCSSA and SAMA guidelines erred was to adopt wholesale into SA medical practice foreign triage protocols incompatible with SA law. Responding to stinging criticism, ${ }^{[32]}$ the CCSSA quoted UK ${ }^{[33]}$ and Canadian precedent ${ }^{[34]}$ to protest that their 'only absolute exclusion' for admission to an ICU was a 'high CFS. [35] Imported British $^{[36]}$ and European COVID-19 guidelines ${ }^{[37]}$ relied extensively on Chinese ${ }^{[38]}$ and other studies listing advanced age as a 'risk factor' or 'prognostic indicator' for COVID-19 mortality, since shown likely to be highly biased. ${ }^{[39]}$ An early Canadian collaboration to develop a triage protocol as far back as 2006 found that old age was not in fact a strong predictor of ICU mortality, yet the authors reported that they were compelled by experts and stakeholders to add age as an exclusion criterion. ${ }^{[12]}$ Patients older than 85 were duly denied access to an ICU at triage. Switzerland ${ }^{[40]}$ and the $U K,{ }^{[41]}$ while not members of the European Union, incorporate the European Convention on Human Rights ${ }^{[42]}$ into their domestic law. ${ }^{[43,44]}$ Public health authorities invoked the European legal principle of proportionality ${ }^{[45]}$ to justify their limitation of the scarce ICU resource to vulnerable groups. ${ }^{[46]}$ The British Medical Association declared that, while direct discrimination based on age or disability would be unlawful, indirect discrimination, given its 'legitimate aim' to save the most lives during the pandemic, would be lawful. ${ }^{[36]}$

The adverse conclusion to be drawn from such approaches is that expensive and scarce ICU health resources should be reserved for the fittest and least vulnerable in society. Recommendations that triage committees or 'death panels' be appointed to distance individual clinicians from the emotional and moral 'trauma' of prohibitive choices ${ }^{[4]}$ only serve to confirm the inherent inhumanity and deadly implications of so doing.

What the COVID-19 pandemic has revealed all too starkly is the hidden political and social prejudices that endure within modern health systems, ${ }^{[48]}$ in which selective care is dispensed mainly for profit at the expense of the socially vulnerable.

It is for these reasons that, after all ethical arguments for and against the allocation of scarce critical care resources are exhausted, the minimum standard expected of any democratic society is compliance with its own law. The SA law is the Constitution, its domestic enabling legislation, and decided cases securing equality and dignity for all. ${ }^{[49]}$ Those are the standards with which the CCSSA and SAMA triage guidelines must comply, unless or until legislation or the courts determine otherwise.

\section{Legislation}

The Constitutional Court has held that SA public health providers are liable for undue delays in providing appropriate emergency care. It exhorts healthcare providers not to slavishly follow protocols that fall short of the standards of emergency care that the public is entitled to expect. ${ }^{[50]}$

The dissemination or publication of unfairly discriminatory material in the form of exclusionary triage guidelines, even in non-binding form, ${ }^{[21]}$ flouts SA equality law: once discrimination exists (which the CCSSA admits it does), the burden of proof that the impugned guidelines are objectively fair, reasonable and justified shifts to the CCSSA and SAMA. They must show that the COVID-19 triage guidelines they recommend are legally and contextually defensible. ${ }^{[21]}$ Healthcare providers remain personally and professionally liable for their own conduct, ${ }^{[51]}$ regardless of whether they have followed guidelines. ${ }^{[50]}$

The incitement or propagation of harm towards others by recommending the denial of emergency critical care and ICU admission on unfair grounds may further offend as hate speech, ${ }^{[52,53]}$ criminal intimidation, ${ }^{[54]}$ and civil or criminal injury. ${ }^{[52]}$ All are as infectious and harmful to society as health epidemics, ${ }^{[55]}$ and can be just as deadly. ${ }^{[56]}$ Only in states of emergency may derogable guaranteed rights be suspended (Constitution, ${ }^{[19]}$ section 37), and no state of emergency was declared for SA COVID-19 pandemic regulation. ${ }^{[57]}$

In May 2020, the United Nations announced that the COVID-19 pandemic was causing 'untold fear and suffering for older people across the world, ${ }^{[58]}$ echoing domestic prohibitions against hate speech, criminal intimidation, and definitions of crimes against humanity specified in the Rome Statute. ${ }^{[59]}$ State or organisational policy that intentionally causes 'great suffering', serious injury or criminal harm to civilian populations must be prosecuted by the signatory country according to the Rome Statute adopted into SA law. ${ }^{[60]}$ Failing that, the International Criminal Court may intervene. The UK, where some 16000 elderly have succumbed to COVID-19 in care homes, ${ }^{[61]}$ is bound by the Rome Statute, as are Switzerland and more than 120 other countries. ${ }^{[62]}$ The USA, where more than 75000 have succumbed to COVID-19 in long-care nursing homes, is not. ${ }^{[63]}$ Victims blame discriminatory critical care protocols for their loss. Judicial reviews will inevitably follow. ${ }^{[64,65]}$

Representative plaintiffs are afforded broader powers under the Constitution $^{[19]}$ (section 38) to enforce guaranteed rights than was previously possible at common law. ${ }^{[6]]}$ Unfair and discriminatory triage practices and protocols may be challenged in court if necessary. ${ }^{[67]}$

\section{Conclusions}

Medical professionals are acutely aware that they bear the burden of professional negligence and unlawful conduct towards patients at the frontlines of the pandemic. ${ }^{[68]}$ Their disquiet at the lack of clear guidance is well founded. ${ }^{[69,70]}$ SA constitutional law sets a higher human rights benchmark than the jurisdictions from which the CCSSA and SAMA draw their triage guidelines. It is for medical authorities and practitioners to rise to the constitutional standard.

\section{Recommendations}

- No patient in pandemic conditions should be unfairly discriminated against when the threat to life for everyone is indiscriminate.

- The COVID-19 scarce resource triage guidelines need to fully align with SA law to provide practitioners with certainty.

- Unfair healthcare discrimination targeting protected groups should be eliminated from ICU triage protocols.

- Less disadvantageous means to achieve the same ends should be applied. ${ }^{[21]}$

- Clinical criteria ${ }^{[71]}$ and professional judgement ought to suffice to assess short- and near-term survivability in triage prioritisation. ${ }^{[32]}$

- Individual circumstances ${ }^{[14]}$ should be determined at point of care..$^{[72]}$

- No one may be refused emergency medical treatment, regardless of age or pre-existing conditions. ${ }^{[23]}$

- If clinical assessment scores are used (such as SOFA or LAPS2 (Laboratory-Based Acute Physiology Score ${ }^{[14]}$ ), the lungs ought to be excluded in single-organ failure in influenza or COVID-19 triage conditions. ${ }^{[12]}$ 
South Africa has a proud history of human rights activism. ${ }^{[73]}$ This is no time for complacency. ${ }^{[74]}$

Declaration. None.

Acknowledgements. None.

Author contributions. Sole author.

Funding. None.

Conflicts of interest. None.

1. World Health Organization. Archived: WHO timeline - COVID-19. 11 March 2020. https://www.who. int/news-room/detail/27-04-2020-who-timeline---covid-19 (accessed 24 May 2020).

2. Stickings T. Coronavirus patients line the corridors in footage from inside Italian hospital, as military trucks transport scores of victims' coffins to be cremated. MailOnline, 19 March 2020. https://www. dailymail.co.uk/news/article-8129959/Military-trucks-transport-Italian-coronavirus-victims-coffinscremated.html (accessed 22 June 2020).

3. Ne'eman A. Do New York State's ventilator allocation guidelines place chronic ventilator users at risk? Clarification needed. The Hastings Centre, 3 April 2020. https://www.thehastingscenter.org/do-newyork-states-ventilator-allocation-guidelines-place-chronic-ventilator-users-at-risk-clarificationneeded/ (accessed 16 June 2020).

4. Parsons JA, Johal HK. Best interests versus resource allocation: Could COVID-19 cloud decisionmaking for the cognitively impaired? J Med Ethics 2020;46(7):447-450. https://doi.org/10.1136/ medethics-2020-106323

5. Churchill LR. On being an elder in a pandemic. The Hastings Centre, 13 April 2020. https://www. thehastingscenter.org/on-being-an-elder-in-a-pandemic/ (accessed 23 June 2020).

6. Miller FG. Why I support age-related rationing of ventilators for Covid-19 patients. The Hastings Miller FG. Why I support age-related rationing of ventilators for Covid-19 patients. The Hastings
Centre, 9 April 2020. https://www.thehastingscenter.org/why-i-support-age-related-rationing-ofventilators-for-covid-19-patients/ (accessed 23 June 2020).

7. Segal JB. Why I don't support age-related rationing during the Covid pandemic. The Hastings Centre, 18 May 2020. https://www.thehastingscenter.org/why-i-dont-support-age-related-rationing-in-treatingcovid-19/ (accessed 23 June 2020)

8. Evans S. SA's healthcare system has only around 3000 critical care hospital beds available $\ldots$ and it is not enough. News24, 20 March 2020. https://www.news24.com/SouthAfrica/News/sas-healthcaresystem-has-only-around-3-000-critical-care-hospital-beds-available-and-it-is-not-enough-20200320 (accessed 25 May 2020).

9. Detsky ME, Harhay MO, Bayard DF, et al. Discriminative accuracy of physician and nurse predictions for survival and functional outcomes 6 months after an ICU admission. JAMA 2017;317(21):2187for survival and functional outcomes 6 months after
2195. https://doi.org/10.3410/f.727630945.793532703

10. Escher M, Ricou B, Nendaz M, et al. ICU physicians' and internists's survival predictions for patients evaluated for admission to the intensive care unit. Ann Intensive Care 2018;8(1):108. https://doi. org/10.1186/s13613-018-0456-9

11. Sinuff T, Adhikari NK, Cook DJ, et al. Mortality predictions in the intensive care unit: Comparing physicians with scoring systems. Crit Care Med 2006;34(3):878-885. https://doi.org/10.1097/01. ccm.0000201881.58644.41

12. Christian MD, Hawryluck L, Wax RS, et al. Development of a triage protocol for critical care during an influenza pandemic. Can Med Assoc J 2006;175(11):1377-1381 (Box 2). https://doi.org/10.1503/ cmaj.060911

13. New York State Task Force on Life and the Law. Ventilator Allocation Guidelines. New York State Department of Health, 2015:205-206. https://www.health.ny.gov/regulations/task_force/reports_ publications/docs/ventilator_guidelines.pdf (accessed 24 May 2020).

14. University of Pittsburgh. A model hospital policy for allocating scarce critical care resources: Allocation of scarce critical care resources during a public health emergency. 23 March 2020, updated 15 April 2020. https://ccm.pitt.edu/?q=content/model-hospital-policy-allocating-scarce-critical-careresources-available-online-now (accessed 23 June 2020).

15. Joynt GM, Gopalan PD, Argent A, et al. The Critical Care Society of Southern Africa Consensus Guideline on ICU Triage and Rationing (ConICTri). S Afr Med J 2019;109(8b):613-269 and South Afr J Crit Care 2019;35(1b):53-65. https://doi.org/10.7196/SAMJ.2019.v109i8b.13947 and https://doi. org/10.7196/SAJCC.2019.v35ilb.380

16. Critical Care Society of Southern Africa. Allocation of scarce critical care resources during the COVID-19 public health emergency in South Africa. Version 3, 5 May 2020. https://criticalcare.org. za/covid-9/ (accessed 15 September 2020).

17. South African Medical Association. Covid-19 resources. https://www.samedical.org/covid-19/main (accessed 22 June 2020).

18. Statistics South Africa. Census 2011: Profile of persons with disabilities in South Africa, p. vii. http:// www.statssa.gov.za/?p=3180 (accessed 20 September 2020).

19. South Africa. Constitution of the Republic of South Africa, 1996. https://www.gov.za/documents/ constitution-republic-south-africa-1996 (accessed 27 September 2020).

20. City Council of Pretoria v Walker (CCT8/97) [1998] ZACC 1; 1998 (2) SA 363; 1998 (3) BCLR 257 (17 February 1998): paras. 29-31.

21. South Africa. Promotion of Equality and Prevention of Unfair Discrimination Act 4 of 2000. http:// www.lawsofsouthafrica.up.ac.za/index.php/browse (accessed 15 September 2020).

22. (CCT32/97) [1997] ZACC 17; 1998 (1) SA 765 (CC); 1997 (12) BCLR 1696 (27 November 1997) at paras 44 and 20

23. National Coalition for Gay and Lesbian Equality v Minister of Justice [1998] ZACC 15; 1999 (1) SA 6 (CC) at para 132 .

24. Statistics South Africa. Mid-year population estimates 2020, p. viii. http://www.statssa.gov.za/?p=13453 (accessed 11 September 2020)

25. Dorrington RE, Bradshaw D, Laubscher R, Nannan N. Rapid Mortality Surveillance Report 2017. Cape Town: South African Medical Research Council, 2019:iii. https://www.samrc.ac.za/sites/default/files/ files/2019-02-06/RapidMortalitySurveillanceReport2017.pdf

26. Task Force of the American College of Critical Care Medicine, Society of Critical Care Medicine. Guidelines for intensive care unit admission, discharge, and triage. Crit Care Med 1999;27(3):633-638. https://doi.org/10.1097/00003246-199903000-00048

27. Robbins R. A system to allocate scarce ventilators and ICU beds gains traction for not counting any group out, STAT, 2 April 2020. https://www.statnews.com/2020/04/02/ventilator-icu-rationingpittsburgh-framework/ (accessed 16 June 2020).

28. Disability Rights UK. Covid 19 and the rights of disabled people - statement supported by disabled people's organisations and allies. 7 April 2020. https://www.disabilityrightsuk.org/news/2020/april/ covid-19-and-rights-disabled-people (accessed 24 May 2020).
29. Fink S. U.S. civil rights office rejects rationing medical care based on disability, age. New York Times, 28 March 2020. https://www.nytimes.com/2020/03/28/us/coronavirus-disabilities-rationingventilators-triage.html (accessed 16 June 2020).

30. Coggon J, Regmi S. Covid-19: Government guidance on emergency rationing of critical care is Coggon J, Regmi S. Covid-19: Government guidance on emergency rationing of critical care is
needed to support professional decision making. BMJ Opinion, 24 April 2020. https://blogs.bmj.com needed to support professional decision making. BMJ Opinion, 24 April 2020. https://blogs.bmj.com/
bmj/2020/04/24/covid-19-government-guidance-on-emergency-rationing-of-critical-care-is-neededbmj/2020/04/24/covid-19-government-guidance-on-emergency-rati

31. National Institute for Health and Care Excellence (NICE). COVID-19 rapid guideline: Critical care in adults. 20 March 2020, last updated 3 September 2020. https://www.nice.org.uk/guidance/ng159 (accessed 22 September 2020).

32. Singh JA, Moodley K. Critical care triaging in the shadow of COVID-19: Ethics considerations. S Afr Med J 2020;110(5):355-359. https://doi.org/10.7196/SAMJ.2020.v110i5.14778

3. National Institute for Health and Care Excellence (NICE). COVID-19 rapid guideline: Critical care 20 March 2020. www.nice.org.uk/guidance/ng159 (accessed 25 May 2020).

34. Geriatric Medicine Research, Dalhousie University, Halifax, Canada. Canadian Study on Health \& Aging, Clinical Frailty Scale: Revised 2008. http://www.managingmds.com/content/Clinical_Frailty_ Scale.pdf (accessed 4 November 2020).

35. Gopalan PD, Joubert IA, Paruk F, et al.; and response by Singh JA, Moodley K. The Critical Care Society of Southern Africa guidelines on the allocation of scarce critical care resources during the COVID-19 public health emergency in South Africa S Afr Med J 2020;110(8):700-703. https://doi. org/10.7196/SAMJ.2020.v110i8.15000

36. British Medical Association. COVID-19 - ethical issues: A guidance note, p. 7. April 2020. https:// www.bma.org.uk/media/2360/bma-covid-19-ethics-guidance-april-2020.pdf (accessed 24 May 2020). 37. Swiss Academy of Medical Sciences. COVID-19 pandemic: Triage for intensive-care treatment under resource scarcity. Swiss Med Wkly 2020;150:w20229. https://doi.org/10.4414/smw.2020.20229

38. Zhou F, Yu T, Du R, et al. Clinical course and risk factors for mortality of adult inpatients with COVID-19 in Wuhan, China: A retrospective cohort study. Lancet 2020;395(10229):1054-1062. COVID-19 in Wuhan, China: A retrospective
https://doi.org/10.1016/s0140-6736(20)30566-3

39. Wynants L, van Calster B, Collins GS, et al. Prediction models for diagnosis and prognosis of covid-19: Systematic review and critical appraisal. BMJ 2020;369:m1328. https://doi.org/10.1136/bmj.m1328

40. United Nations and the Rule of Law. Switzerland: Implementation of the European Convention on Human Rights. https://www.un.org/ruleoflaw/blog/portfolio-items/switzerland-implementation-ofthe-european-convention-on-human-rights/ (accessed 23 June 2020).

41. United Kingdom. European Union (Withdrawal) Act 2018. https://www.legislation.gov.uk/ ukpga/2018/16/contents/enacted (accessed 5 July 2020).

42. European Convention on Human Rights. http://www.hri.org/docs/ECHR50.html\#C.Art1 (accessed 28 June 2020).

43. Epiney A. How does European Union law influence Swiss law and Swiss policies? In: Nahrath S, Varone F, eds. Rediscovering Public Law and Public Administration in Comparative Policy Analysis: A Tribute to Peter Knoepfel. Lausanne, Switzerland: EPFL Press, Rolex Learning Center, 2009:179-196. https:// core.ac.uk/download/pdf/20658621.pdf (accessed 23 June 2020).

44. United Kingdom. Human Rights Act 1998 (c42) sl. https://www.legislation.gov.uk/ukpga/1998/42/ contents (accessed 5 July 2020)

45. Foster C. Simple rationality? The law of healthcare resource allocation in England. J Med Ethics 2007;33(7):404-407. https://doi.org/10.1136/jme.2006.017905

46. Swiss Academy of Medical Sciences. Medical ethical guidelines: Intensive-care interventions. Swis Med Wkly 2015;145:w14109 (paras 7.4 and 7.6). https://doi.org/10.4414/smw.2015.14109

47. Truog RD, Mitchell C, Daley GQ. The toughest triage - allocating ventilators in a pandemic. N Engl Med 2020;382:1973-1975. https://doi.org/10.1056/nejmp2005689

48. McKinney EL, McKinney V, Swartz L. COVID-19, disability and the context of healthcare triage in South Africa: Notes in a time of pandemic. Afr J Disabil 2020;9:a766. https://doi.org/10.4102/ajod. v9i0.766

49. Albertyn C. Contested substantive equality in the South African Constitution: Beyond social inclusion towards systemic justice. S Afr J Hum Rights 2018;34(3):441-468. https://doi.org/10.10 80/02587203.2018.1550938

50. Oppelt v Head: Health, Department of Health Provincial Administration: Western Cape [2015] ZACC 33 para $36,76,82-84$

51. R v Van Schoor 1948 (4) SA 349 (C).

52. Qwelane v South African Human Rights Commission and Another (686/2018)[2019] ZASCA 167;[2020] 1 All SA 325 (SCA); 2020 (2) SA 124 (SCA); 2020 (3) BCLR 334 (SCA) (29 November 2019), para 96(d). declared s10 of the Promotion of Equality and Prevention of Unfair Discrimination Act 4, 2000 unconstitutional; pending before the Constitutional Court (22 September 2020).

53. South Africa. B9-2018, Prevention and Combating of Hate Crimes and Hate Speech Bill. https:// www.gov.za/documents/prevention-and-combating-hate-crimes-and-hate-speech-bill-b9-2018-13Www.gov.za/documents/prevention-and
apr-2018-0000 (accessed 26 May 2020).

54. South Africa. Intimidation Act 72, $1982 \mathrm{sl}(1)$ (b) and 1(2) declared unconstitutional in Moyo and South Africa. Intimidation Act 72, $1982 \mathrm{sl}(1)(\mathrm{b})$ and $1(2)$
Another v Minister of Police and Others [2019] ZACC 40 .

55. Bayliss EA. Epidemics, pandemics and outbreaks, lecture 1, University of Pittsburgh. https://teaching. pitt.edu/pitt-online/programs/moocs/epidemics-pandemics-and-outbreaks/ (accessed 30 June 2020). 56. Burman R, Cairns R, Canestrini S, et al. Making ordinary decisions in extraordinary times. BM 2020;370:m3268. https://doi.org/10.1136/bmj.m3268

57. South Africa. Disaster Management Act 57 of 2002. http://www.lawsofsouthafrica.up.ac.za/index.php/ browse (accessed 15 September 2020)

58. UNECE Corona Virus Advisory. Policy Brief: The impact of the COVID-19 pandemic on olde persons. United Nations, May 2020. https://www.unece.org/info/media/news/population/2020/theimpact-of-the-covid-19-pandemic-on-older-persons/doc.html (accessed 23 June 2020).

59. Rome Statute of the International Criminal Court, 1998. Article 7 1.(h), (j) and (k). https://legal. un.org/icc/statute/99_corr/cstatute.htm (accessed 16 June 2020).

60. South Africa. Implementation of the Rome Statute of the International Criminal Court Act 27 of 2002. http://www.lawsofsouthafrica.up.ac.za/index.php/browse (accessed 15 September 2020).

61. Booth R, Duncan P. More than 16,000 people in UK care homes have died from coronavirus. Guardian, 16 June 2020. https://www.theguardian.com/world/2020/jun/16/more-than-16000-people-in-ukcare-homes-have-died-from-coronavirus (accessed 19 October 2020).

62. United Nations Treaty Collection Depository. Rome Statute of the International Criminal Court. https:// United Nations Treaty Collection Depository. Rome Statute of the International Criminal Court. https://
treaties.un.org/Pages/ViewDetails.aspx?src=TREATY\&mtdsg_no=XVIII-10\&chapter=18\&clang=_en (accessed 28 September 2020).

63. Abrams A. COVID-19 is still devastating nursing homes. The Trump administration isn't doing much to stop it. Time, 11 September 2020. https://time.com/5887699/nursing-homes-covid-19-federal-help/ (accessed 20 September 2020).

64. Booth R. Releasing English hospital patients into care homes 'not illegal'. Guardian, 21 June 2020 https://www.theguardian.com/world/2020/jun/21/releasing-english-hospital-patients-into-carehomes-not-illegal (accessed 30 June 2020).

65. Gallagher S. My dad died from coronavirus in a care home. Now I'm taking legal action against the government that made it a death trap. Independent, 28 August 2020. https://www.independent.co.uk/ life-style/coronavirus-care-home-death-cathy-gardner-michael-gibson-matt-hancock-a9682156.htm (accessed 23 September 2020).

66. Plasket C. South Africa. Ann Am Acad Pol Soc Sci 2009;622(1):256-268. https://doi org $/ 10.1177 / 0002716208328477$ 
67. Heywood M. South Africa’s Treatment Action Campaign: Combining law and social mobilization to realize the right to health. J Hum Rights Pract 2009;1(1):14-36. https://doi.org/10.1093//human/hun006 68. MPS Column. COVID-19: National guidelines needed to support medical profession. Medical Brief, 10 June 2020. https://www.medicalbrief.co.za/archives/covid-19-national-guidelines-needed-to-support10 June 2020. https://www.medicalbrief.co.za/ardiv
medical-profession/ (accessed 11 August 2020).

69. Castelyn CdeV, Viljoen IM, Dhai A, Pepper MS. Resource allocation during COVID-19: A focus on vulnerable populations. S Afr J Bioethics Law 2020;13(2). https://doi.org/10.7196/SAJBL.2020.v13i2.730 . Burman R, Cairns R, Canestrini S, et al. Making ordinary decisions in extraordinary times. BM] 2020;370:m3268. https://doi.org/10.1136/bmj.m3268

71. Baker T, Schell CO, Petersen DB. Essential care of critical illness must not be forgotten in the COVID-19 pandemic. Lancet 2020;395(10232):1253-1254. https://doi.org/10.1016/s0140-6736(20)30793-5

72. Duggan NM, Liteplo AS, Shokoohi H, Goldsmith AJ. Using lung point-of-care ultrasound in suspected COVID-19: Case series and proposed triage algorithm. Clin Pract Cases Emerg Med 2020;4(3):289-294. https://doi.org/10.5811/cpcem.2020.7.47912
73. South African Lancet National Commission. Confronting the right to ethical and accountable quality health care in South Africa: Synopsis of the findings and recommendations of the Consensus Report of health care in South Africa: Synopsis of the findings and recommendations of the Consensus Report of
the South African Lancet National Commission. December 2018. http://rhap.org.za/confronting-theright-to-ethical-and-accountable-quality-healthcare-in-south-africa-lancet-national-commissionright-to-ethical-and-accountable-quality-heal

74. Medical Brief. SA's worst-case COVID model: No ICU beds by June, 48,000 deaths by November. 20 May 2020. https://www.medicalbrief.co.za/archives/sas-worst-case-covid-model-no-icu-beds-byjune-48000-deaths-by-november/ (accessed 25 May 2020).

Accepted 28 October 2020. 